\title{
Environment and cultural heritage: an important link to develop suitable protection strategies
}

\section{Editorial}

In recent decades, the built heritage has been degraded more than in the past, which suggests that air pollution is one of the most dangerous agents in the degradation and alteration processes. Environmental parameters, such as temperature, humidity, precipitation, direction and frequency of winds, pollutants are the main causes of the deterioration phenomena. Many studies have shown the close correlation between these parameters and the formation and development of different degradation phenomena, such as black crusts, salts crystallization, detachments, erosion and alveolization. Black crusts and salts crystallization represent the more common and dangerous ones.

Black crusts are the result of the interaction between atmospheric pollution, produced by human activity, and calcareous buildings located in urban areas. ${ }^{1-7}$ In particular, their formation is related to the growth of gypsum on stone substrates, in particular limestone and marble, sheltered from water and attacked by an $\mathrm{SO}_{2}$-polluted atmosphere. The degradation mainly interests those architectural surfaces protected from washing out which usually give rise to a more severe decay of the stone including loss of material. The typical color of such surfaces is black, caused by the accumulation of air pollutants, especially carbon particles taken from the incomplete combustion of fossil fuels. ${ }^{8}$ Geochemical studies carried out on different historical monuments showed that some trace elements, such as heavy metals, in the black crusts provide useful information about pollution sources. ${ }^{9-12}$ Furthermore this geochemical approach can represent an important tool to evaluate the best strategies for the protection and conservation of the built heritage, like cleaning procedures In some cases, in fact, higher amounts of heavy metals such as $\mathrm{Pb}, \mathrm{Zn}, \mathrm{Cu}$, $\mathrm{Ni}$, As and V, due to high geochemical mobility, are detected into the substrate and can become catalysts for the development of further decay of the stone substrate. ${ }^{11}$ Salts crystallization is one of the most dangerous weathering processes in the stone materials, mainly porous limestone rocks. Macroscopically, this process can produce different damages such as exfoliation, erosion, flaking, and loss of material, flaking, and disaggregation of the material. ${ }^{13}$

Salt crystallization takes place into the porous materials when specific supersaturating and thermodynamic conditions occur. Among different salts, an important role is played by sodium sulphate which can crystallize both as mirabilite $\left(\mathrm{Na}_{2} \mathrm{SO}_{4} \times 10 \mathrm{H}_{2} \mathrm{O}\right)$ and the nitrite $\left(\mathrm{Na}_{2} \mathrm{SO}_{4}\right)$, depending on the humidity and temperature conditions. ${ }^{14}$

For this reason, there is an increasing need of preventive measures against potential damages. These procedures include the monitoring of environmental parameters, which are also related to the efficacy of protective and consolidating products for restoration. On the basis of these considerations, research in this field is useful both for monitoring the environment and to safe guard our monuments.

\author{
Volume I Issue 2 - 2016 \\ Mauro Francesco La Russa \\ Department of Biological, University of Calabria, Italy
}

Correspondence: Mauro Francesco La Russa, Department of Biological, Ecological and Earth Science, University of Calabria, Italy, Email mlarussa@unical.it

Received: September 27, 2016 | Published: November 25, 2016

\section{Acknowledgements}

None.

\section{Conflict of interest}

The author declares no conflict of interest.

\section{References}

1. Amoroso GG, Fassina V. Stone Decay and Conservation. UK: Elsevier Science Publisher; 1983. $453 \mathrm{p}$

2. Zappia G, Sabbioni C, Riontino C, et al. Exposure tests of building materials in urban atmosphere. Sci Total Environ. 1998;224(1-3):235-244.

3. Brimblecombe P. Urban Air Pollution-European Aspects. In: Finger J, et al. editors. Springer Netherlands; 1998. p. 7-20

4. Brimblecombe P. J Archit Conserv. 2000;6(30)

5. Bonazza A, Sabbioni C, Ghedini N, et al. Pollut Atmos, Numèro Spèc. 2007. $7 \mathrm{p}$.

6. Ghedini N, Sabbioni C, Bonazza A, et al. Chemical-Thermal quantitative methodology for carbon speciation in damage layers on building surfaces. Environ Sci Technol. 2006;40(3):939-944.

7. Moropoulou A, Bisbikou K, Torfs K, et al. Origin and growth of weathering crusts on ancient marbles in industrial atmosphere. Atmospheric Environment. 1998;32(6):967-982.

8. Ghedini N, Sabbioni C, Bonazza A, et al. Chemical-thermal quantitative methodology for carbon speciation in damage layers on building surfaces. Environ Sci Tecnol. 2006;40(3):939-944.

9. Barca D, Belfiore CM, Crisci GM, et al. Application of laser ablation ICPMS and traditional techniques to the study of black crusts on building stones: a new methodological approach. Environmental Science and Pollution Research. 2010;17(8):1433-1447.

10. Barca D, Belfiore CM, Crisci GM, et al. A new methodological approach for the chemical characterization of black crusts on building stones: a case study from the Catania city centre (Sicily, Italy). Journal of Analytical Atomic Spectrometry. 2011;26(5):1000-1011. 
11. La Russa MF, Belfiore CM, Comite V, et al. Geochemical study of black crusts as a diagnostic tool in cultural heritage. Applied Physics A. 2013;113(4):1151-1162.

12. Ruffolo SA, Comite V, La Russa MF, et al. An analysis of the black crust from the Seville Cathedral: A challenge to deepen the understanding of the relationships among microstructure, microchemical features and pollution sources. Science of The Total Environment. 2015;502:157-166.
13. Silvestro AR, Valeria C, Mauro FR, et al. An analysis of the black crusts from the Seville Cathedral: A challenge to deepen the understanding of the relationships among microstructure, microchemical features and pollution sources. Science of the Total Environment. 2015;502(1):157-166.

14. La Russa MF, Ruffolo SA, Belfiore CM, et al. PeriodMineral. 82:113-127.

15. Flatt RJ. Salt damage in porous materials: how high supersaturations are generated. Journal of Crystal Growth. 2002;42(3-4):435-454. 